\title{
Deteksi Gen Ketahanan Terhadap Gsb-4 (Gummy Stem Blight) pada Tanaman Melon (Cucumis Melo L.)
}

\author{
Detection of Gummy Stem Blight Resistance Gene in Melon (Cucumis Melo L.)
}

Ganies Riza Aristya*, Aisha Rizky Rahmawati, dan Budi Setiadi Daryono

Laboratorium Genetika, Fakultas Biologi, Universitas Gadjah Mada Yogyakarta

Jln. Teknika Selatan, Sekip Utara Yogyakarta, 55281

E-mail: ganies_riza@ugm.ac.id *Penulis korespondensi

\begin{abstract}
Producing superior melons whose resistance of gummy stem blight $(G s b-4)$ is a best way to detract gummy stem blight disease. Therefore, understanding the resistance gene of gummy stem blight is crucial. The aim of the research was to detect a gummy stem blight resistant gene (Gsb-4) in 18 cultivar melons and 1 cultivar cucumber. Amplification results using Simple Sequence Repeat (SSR) with specific primers CMTA170a showed a single band of 120 bp and specific primer CMCT160a+b showed a single band of 212 bp. All cultivar had a gummy stem blight resistant gene (Gsb-4), even homozigot and heterozigot.
\end{abstract}

Keywords: Melon, Gsb-4, Simple Sequence Repeat, cultivated variety

\begin{abstract}
Abstrak
Perakitan melon tahan penyakit gummy stem blight (Gsb-4) merupakan upaya yang dapat dilakukan untuk menanggulangi penyakit gummy stem blight. Untuk itu harus diketahui ada tidaknya gen ketahanan terhadap gummy stem blight. Tujuan penelitian ini adalah mendeteksi adanya gen ketahanan terhadap gummy stem blight pada 18 kultivar melon dan 1 kultivar mentimun. Hasil amplifikasi menggunakan penanda molekular Simple Sequence Repeat (SSR) dengan primer spesifik yaitu CMTA170a menunjukkan pita berukuran 120 bp sedangkan dengan primer CMCT160a+b menunjukkan pita berukuran 212 bp. Hasil yang diuji menunjukkan bahwa semua kultivar melon memiliki gen ketahanan terhadap gummy stem blight baik homozigot maupun heterozigot.
\end{abstract}

Kata kunci: Melon, Gsb-4, Simple Sequence Repeat, kultivar

Diterima: 18 Desember 2015, disetujui: 14 Januari 2016

\section{Pendahuluan}

Salah satu penyakit penting pada tanaman melon adalah busuk pangkal batang atau gummy stem blight yang disebabkan oleh pathogen berupa jamur Didymella bryoniae (Adalberto dkk., 2010). Gummy stem blight adalah penyakit yang disebabkan oleh jamur Ascomicota yaitu Didymella bryoniae (Auersw.) Rehm, Mycosphaerella citrullina (C.O.Sm.) Gross., dan Phoma cucurbitacearum (Fr.:Fr.) Sacc. (Wolukau et al., 2009; Choi et al., 2010). Gejala awal tanaman yang terserang patogen ini adalah luka sayatan yang menyebabkan buah, sulur atau akar lateral terpotong. Luka sayatan tersebut dapat memanjang hingga ke batang tanaman sehingga menyebabkan tanaman layu kemudian mati (Zhang dkk., 2014). Penyakit ini biasanya terjadi pada masa pemasakan dan pematangan buah (Furukawa dkk., 2007). Usaha yang dapat dilakukan untuk menekan penyakit gummy stem blight adalah penyemprotan fungisida seperti "azoxystrobin and kresoxym-methyl" dan melakukan persilangan untuk menghasilkan tanaman hibrid tahan terhadap jamur $D$. bryoniae (Utkhede dan Koch, 2002; Grube dkk., 2011).

Persilangan untuk menghasilkan tanaman yang memiliki ketahanan terhadap gummy stem blight telah beberapa kali dilakukan. Penelitian sebelumnya telah menjelaskan adanya gen pengkode ketahanan terhadap gummy stem blight. Menurut Franzt dan Jahn (2004), pewarisan dan analisis segregasi gen ketahanan 
terhadap jamur patogen Didymella bryoniae penyebab penyakit gummy stem blight ditentukan oleh lima gen bebas pada melon yang terdapat pada lokus Gsb-1 atau Mc yang merupakan gen tunggal dominan dari PI 140471, Gsb-2 yang merupakan gen tunggal dominan dari PI 157082, Gsb-3 yang merupakan gen tunggal dominan dari PI 511890, Gsb-4 yang merupakan gen tunggal dominan dari PI 482398, dan $g s b-5$ yang merupakan gen tunggal resesif dari PI 482399. Ying dkk., (2012) mengembangkan primer spesifik yaitu CMTA170a dan CMCT160a+b untuk mengetahui pewarisan gen $G s b-4$ pada keturunan melon 'Baipicui' dan 'PI482398'. Primer spesifik terdiri atas primer forward dan reverse yang berbeda. Pada penelitian ini, primer tersebut digunakan untuk mendeteksi adanya gen Gsb-4 pada beberapa kultivar melon di Indonesia. Deteksi gen $G s b-4$ dilakukan dengan Polymerase Chain Reaction (PCR) yaitu teknik amplifikasi (penggandaan) DNA secara in vitro (Koolman dan Rohm, 1994).

Hasil amplifikasi akan menunjukkan gen ketahanan terhadap gummy stem blight (Gsb-4). Hal tersebut penting diketahui untuk proses perakitan melon unggul tahan penyakit gummy stem blight. Tujuan penelitian ini adalah mengetahui keberadaan gen ketahanan terhadap gummy stem blight (Gsb-4) pada 18 kultivar melon di Indonesia.

\section{Metode Penelitian}

Bahan tanaman berupa daun tanaman melon diambil dari rumah kaca Pusat Inovasi Agro-Teknologi (PIAT) UGM di Kalitirto, Berbah, Sleman, Yogyakarta yang terdiri atas 3 kultivar melon hasil persilangan dari inovasi Laboratorium Genetika Fakultas Biologi UGM yaitu 'Tacapa', 'Tania', dan 'Talita' serta 15 melon komersial yaitu 'Sky Rocket', 'Sonya', 'Action 434', 'Honey Globe', 'Kalila', 'Mai 119', 'Sun Lady', 'Ladika', 'Orio', 'Fantasy', 'Elegant', 'Putri Kencana', 'Apollo', 'Virgo', dan 'PI 371795'. Mentimun 'Hercules' sebagai pembanding (outgroup). Melon kultivar 'Tacapa', 'Tania', dan 'Talita' merupakan melon hibrid yang memiliki keunggulan dalam kualitas buah dan sifat ketahanannya terhadap jamur tepung sehingga diproyeksikan memiliki sifat ketahanan terhadap jamur Didymella bryoniae. Sedangkan 15 melon kultivar lainnya merupakan melon hibrid yang telah dikomersilkan dan memiliki keunggulan dalam kualitas buah namun belum diketahui sifat ketahanannya terhadap jamur.

Sebanyak 5 biji setiap kultivar melon dan 1 kultivar mentimun dikecambahkan dalam kondisi lembab selama 3 hari. Biji berkecambah ditandai keluarnya radikula. Kemudian kecambah dipindahkan ke dalam medium tanah pada polybag. Tanah tersebut diambil dari kebun di PIAT UGM tanpa disterilkan terlebih dahulu. Tanaman melon disiram setiap dua hari sekali dan setelah berumur 4 minggu, daun melon yang tidak terinfeksi jamur maupun virus dipotong untuk diisolasi DNA-nya. Selama proses penanaman melon tidak dilakukan injeksi atau spray jamur Didymella bryoniae pada tanaman melon.

Selanjutnya dilakukan ekstraksi DNA menggunakan KIT Nucleon-Phytopure (Illustra DNA Extraction KIT Phytopure ${ }^{\mathrm{TM}}$ ) yang terdiri dari Reagen I, Reagen II, dan Resin. Reagen I mengandung potasium SDS dan enzim selulase untuk melarutkan selulosa yang terdapat pada dinding sel, Reagen II mengandung potasium SDS yang berfungsi melarutkan komponen lipid pada membran sel sehingga sel mengalami lisis, sedangkan Resin yang mengandung asam borik bebas yang dapat membentuk ikatan kovalen dengan polisakarida menghasilkan lapisan semi solid untuk dibuang sehingga supernatan menjadi bening. Modifikasi dilakukan pada waktu inkubasi, penambahan kloroform untuk mendapatkan supernatan yang banyak dan bening. Fungsi kloroform adalah menghilangkan debris sel serta mampu mendenaturasi protein dan polisakarida.

Metode modifikasi selengkapnya diuraikan sebagai berikut. Sebanyak 0,3 g daun melon yang sehat yang sebelumnya telah dibekukan digerus dengan $500 \mu 1$ Reagen I Phytopure. Ekstrak daun kemudian dipindahkan ke dalam tabung mikro $1500 \mu 1$, ditambahkan Reagen II Phytopure sebanyak $200 \mu$, dan diinkubasi pada suhu $75^{\circ} \mathrm{C}$ selama 20 menit kemudian segera dimasukkan freezer selama 10 menit. Selanjutnya ditambahkan $400 \mu \mathrm{l}$ 
kloroform dingin dan $20 \mu 1$ resin Phytopure lalu diinversi selama 30 menit.

Campuran dipisahkan menggunakan sentrifugator pada kecepatan $1300 \mathrm{rpm}$ selama 10 menit pada suhu ruang. Fase cair bagian atas (supernatan) dipindahkan ke tabung yang baru. Kemudian ditambahkan kloroform $200 \mu 1$ dan akuades hingga volume total $400 \mu \mathrm{l}$ kemudian disentrifugasi kembali $1300 \mathrm{rpm}$ selama 10 menit pada suhu ruang. Selanjutnya supernatan yang bening dipindahkan ke tabung baru dan ditambahkan isopropanol dingin sebanyak 200 $\mu 1$ kemudian digoyang perlahan selama 1 menit. Campuran tersebut selanjutnya disentriugasi $10.000 \mathrm{rpm}$ selama 10 menit pada suhu ruang. Pelet yang diperoleh dicuci dengan alkohol $70 \%$ sebanyak 3 kali kemudian dikeringanginkan dan dilarutkan pada $50 \mu \mathrm{l}$ buffer TE. Pelet tersebut merupakan endapan DNA hasil ekstraksi.

Konsentrasi dan kemurnian DNA secara kuantitatif diukur menggunakan metode spektrofotometri dengan alat spektrofotometer UV (GeneQuant - 1300) pada panjang gelombang $260 \mathrm{~nm}$ dan $280 \mathrm{~nm}$. Sedangkan kualitas DNA diuji menggunakan perbandingan hasil elektroforesis sampel DNA dengan marka pada gel agarosa $0,8 \%$.

Hasil isolasi DNA diamplifikasi menggunakan metode Polymerase Chain Reaction (PCR) dengan dua pasang primer CMTA170a dan CMCT160a+b (Ying dkk., 2012) yang terdiri atas forward primer dan reverse primer. Volume reaksi amplifikasi PCR yang digunakan adalah $25 \mu 1$, yang masingmasing terdiri atas 2X KAPA Taq Extra HotStart ReadyMix with dye, forward primer 25 pmol, reverse primer $25 \mathrm{pmol}$, dan $200 \mathrm{nM}$ template DNA. Reaksi amplifikasi PCR dengan denaturasi awal $95^{\circ} \mathrm{C}$ selama 3 menit, diikuti dengan 35 siklus yang masing-masing terdiri atas tahapan denaturasi pada suhu $94^{\circ} \mathrm{C}$ selama15 detik. Kemudian diikuti dengan penempelan primer (annealing) pada suhu $51^{\circ} \mathrm{C}$ selama 15 detik dan pemanjangan (elongation) pada suhu $72^{\circ} \mathrm{C}$ selama 1 menit. Pada akhir reaksi ditambahkan satu tahapan final extension pada suhu $72^{\circ} \mathrm{C}$ selama 5 menit.

DNA hasil amplifikasi dianalisis menggunakan elektroforesis gel agarosa $2 \%$ menggunakan marka 50 bp (Roche Molecular Biochemicals DNA Molecular Weight Marker
XIII) untuk mendeteksi adanya gen ketahanan terhadap gummy stem blight. Sifat heterozigositas gen ketahanan terhadap gummy stem blight diuji elektroforesis gel agarosa 3,8\% menggunakan marka 20 bp (20 bp DNA ladder Jena Bioscience) untuk primer CMTA170a dan marka50 bp (Roche Molecular Biochemicals DNA Molecular Weight Marker XIII ) untuk primer CMCT160a+b. Marka DNA digunakan untuk membantu menentukan ukuran DNA hasil amplifikasi PCR. Hasil elektroforesis selanjutnya diperjelas gambarnya menggunakan pewarna good view dan difoto di bawah penyinaran UV.

\section{Hasil dan Pembahasan}

Berdasarkan Gambar 1 diketahui bahwa pita DNA yang muncul terletak diatas ladder dekat dengan sumuran. Hal ini disebabkan ukuran genom melon besar berkisar antara 450500 Mbp (Pech dkk., 2001). Ladder yang digunakan berukuran $1 \mathrm{~Kb}$ dengan ukuran tertinggi $12 \mathrm{Kbp}$ sehingga genom melon terletak di atasnya.

Hasil pengukuran konsentrasi dan kemurnian DNA dapat ditunjukkan pada Tabel1. Konsentrasi DNA dapat ditentukan melalui persamaan berikut :

$[\mathrm{DNA}]=\mathrm{OD}_{260} \times \mathrm{FC} \times 50 \mu \mathrm{g} / \mathrm{ml}$

(Sambrook \& Russel, 2001)

Keterangan : [DNA] : konsentrasi DNA $(\mu \mathrm{g} / \mathrm{ml})$

$$
\begin{array}{ll}
\mathrm{OD}_{260} & \begin{array}{l}
\text { : nilai absorbansi pada } \\
\text { panjang gelombang } 260 \mathrm{~nm}
\end{array} \\
\mathrm{FC} & \text { : faktor pengenceran }
\end{array}
$$

Tingkat kemurnian DNA dapat diketahui dari rasio besarnya absorbansi (OD) pada panjang gelombang $260 \mathrm{~nm}$ dan $280 \mathrm{~nm}$ dengan persamaan sebagai berikut:

$$
\mathrm{DNA}=\mathrm{OD}_{260}: \mathrm{OD}_{280}
$$

(Sambrook \& Russel, 2001)

Keterangan : DNA : kemurnian DNA

$$
\begin{aligned}
\mathrm{OD}_{260}: & \text { besarnya absorbansi pada } \\
& \text { panjang gelombang } 260 \mathrm{~nm} \\
\mathrm{OD}_{280}: & \text { besarnya absorbansi pada } \\
& \text { panjang gelombang } 280 \mathrm{~nm}
\end{aligned}
$$


Berdasarkan Tabel 1 dapat diketahui bahwa kuantitas DNA yang diperoleh berkisar antara 400-1898 $\mu \mathrm{g} / \mathrm{ml}$ dengan kemurnian 1,5-2. Keberagaman konsentrasi DNA ini disebabkan karena pada saat ekstraksi DNA total banyak yang terbuang. Kemurnian yang dianjurkan untuk amplifikasi DNA adalah 1,8-2 namun kemurnian yang didapat sudah dapat menunjukkan hasil amplifikasi yang bagus.

Amplifikasi PCR template DNA melon menggunakan primer spesifik SSR yaitu CMTA170a dan CMCT160a+b dapat menghasilkan pita produk amplifikasi yang jelas sehingga mengindikasikan bahwa kualitas dan kuantitas DNA yang diekstraksi cukup memadai dan pasangan primer yang digunakan cocok. DNA template hasil amplifikasi diuji pada gel agarosa $2 \%$ dan 3,8\%. Konsentrasi ini didasarkan bahwa DNA template hasil amplifikasi memiliki ukuran yang kecil sehingga untuk memisah digunakan konsentrasi gel yang tinggi. Hasil uji tersebut menunjukkan bahwa seluruh kultivar melon dan satu kultivar mentimun memiliki gen ketahanan terhadap gummy stem blight dilihat berdasarkan munculnya pita DNA (Gambar 2 dan 3) sehingga melon dan mentimum resisten terhadap gummy stem blight. Gen penyandi ketahanan melon terhadap gummy stem blight dapat teramplifikasi pada panjang $120 \mathrm{bp}$ pada primer CMTA170a dan 212 bp pada CMCT160a+b berupa pita monomorfik.

Heterozigositas sifat ketahanan terhadap gummy stem blight pada beberapa kultivar melon diketahui dari munculnya dua alel berukuran 120 bp dan 140 bp pada primer CMTA170a, sedangkan pada primer CMCT160a+b berukuran 212 bp dan 200 bp. Pengetahuan mengenai heterozigositas gen tertentu merupakan salah satu keunggulan penanda molekular simple Sequence Repeat (Carmen de Vecente dan Fulton, 2003). Pada primer CMTA170a diketahui bahwa melon kultivar TALITA, Apollo, Orio, Mai 119, Kalila, Virgo, Sun Lady, Action 434, Honey Globe, dan Sky Rocket memiliki sifat heterozigot (Gambar 4). Sedangkan pada primer CMTA160a+b melon yang memiliki sifat heterozigot adalah Fantasy, Kalila, Sun Lady, PI 371795. Perbedaan gen dominan yang terjadi yaitu homozigot dan heterozigot disebabkan oleh pasangan gen yang masing-masing diterima dari induknya.

Dijumpainya penyakit gummy stem blight pada tanaman melon yang mengandung gen ketahanan terhadap jamur tersebut dapat diakibatkan oleh lingkungan yang terlalu lembab dan terinfeksi jamur yang ditularkan oleh tanaman lain (Lou et al., 2012). Penelitian oleh Furukawa et al (2007) menunjukkan bahwa penyakit gummy stem blight pada Cucurbitaceae di Jepang banyak muncul di musim panas dan awal musim gugur. Udara menjadi lebih lembab saat musim panas dan awal musim gugur. Sedangkan di Benua Amerika, penyakit gummy stem blight banyak ditemukan di daerah beriklim lembab dengan curah hujan yang tinggi, seperti California Selatan, Florida, Charleston, Tompkins, Colleton, Lexington, Allendale, dan Onondaga (Keinath dkk., 1995).

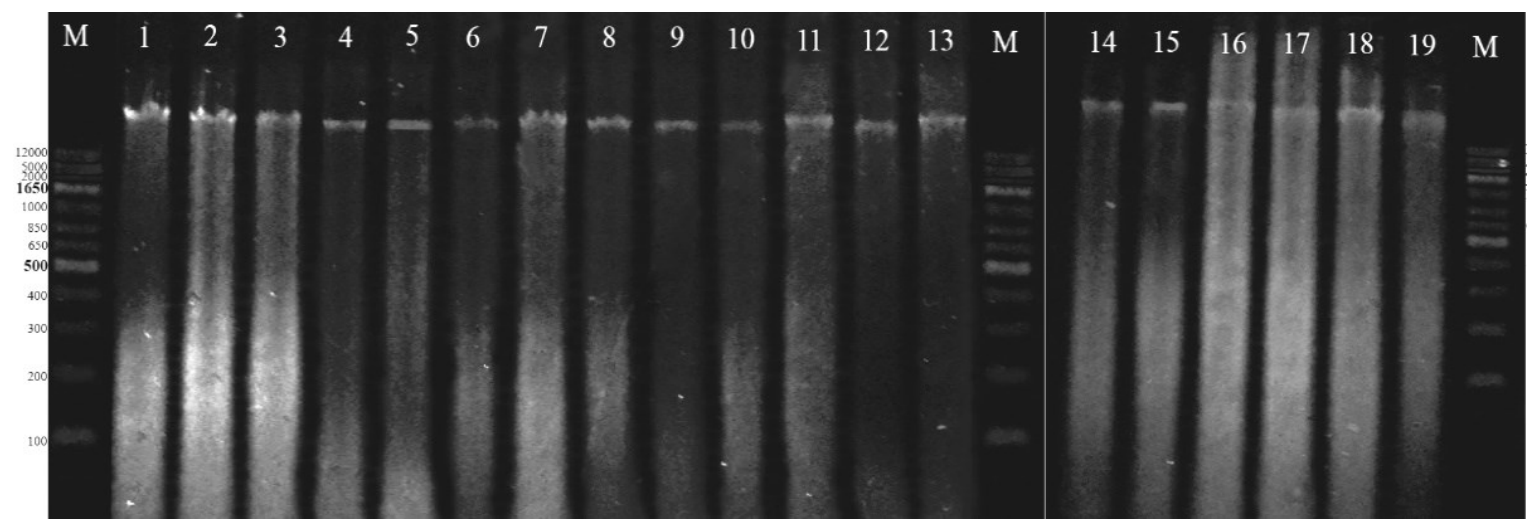

Gambar 1. Hasil uji kualitatif DNA melon kultivar (1) Action 434, (2) Apollo, (3) Elegant, (4) Fantasy, (5) Honey Globe, (6) Kalila, (7) Ladika, (8) Mai 119, (9) Orio, (10) PI 371795, (11) Putri Kencana, (12) Sonya, (13) Sky Rocket, (14) Sun Lady, (15)Virgo, (16) Tacapa, (17) Tania, (18) Talita, (19) Hercules. 
Tabel 1. Hasil uji kuantitatif DNA melon.

\begin{tabular}{cccc}
\hline \hline No & Sampel & Kemurnian & Konsentrasi $(\boldsymbol{\mu g} / \mathbf{m l})$ \\
\hline \hline 1 & Action 434 & 1,714 & 1199 \\
2 & Apollo & 1,583 & 1898 \\
3 & Elegant & 1,875 & 1498 \\
4 & Fantasy & 2 & 799 \\
5 & Honey Globe & 2 & 400 \\
6 & Kalila & 1,667 & 1498 \\
7 & Ladika & 1,67 & 500 \\
8 & Mai 119 & 1,5 & 300 \\
9 & Orio & 1,67 & 500 \\
10 & PI 371795 & 1,667 & 1498 \\
11 & Putri Kencana & 1,75 & 699 \\
12 & Sonya & 1,8 & 899 \\
13 & Sky Rocket & 1,5 & 1199 \\
14 & Sun Lady & 1,5 & 1498 \\
15 & Virgo & 1,5 & 599 \\
16 & Tacapa & 1,778 & 1598 \\
17 & Tania & 1,556 & 1399 \\
18 & Talita & 1,562 & 2498 \\
19 & Hercules & 2 & 599 \\
\hline \hline
\end{tabular}

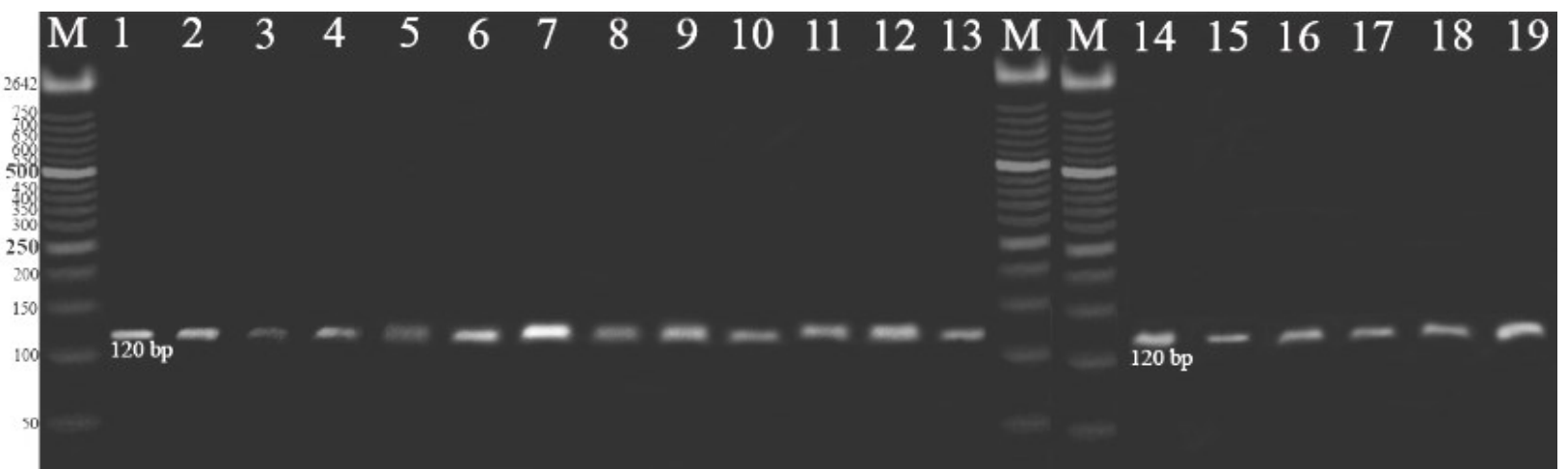

Gambar 2. Hasil amplifikasi PCR-SSR DNA menggunakan gel agarosa $2 \%$ dengan primer CMTA170a M: Marker 50 bp; (1) Tacapa, (2) Tania, (3) Talita, (4) Apollo, (5) Orio, (6) Mai 119, (7) Fantasy, (8) Putri Kencana, (9) Kalila, (10) Ladika, (11) Virgo, (12) Elegant, (13) Sun Lady, (14) PI 371795, (15) Action 434, (16) Honey Globe, (17) Sky Rocket, (18) Sonya, dan (19) Hercules.

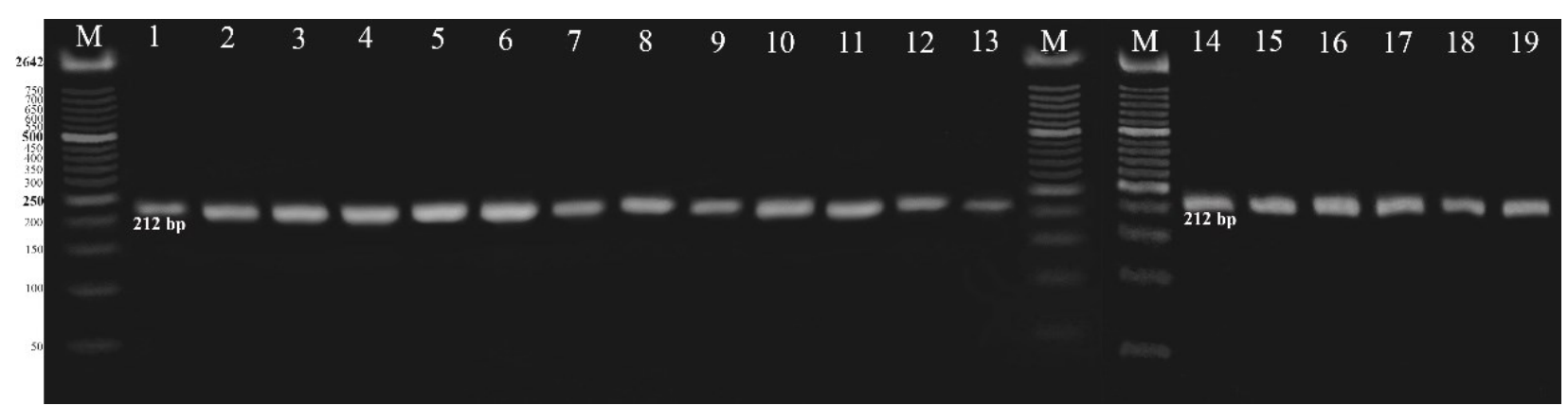

Gambar 3. Hasil amplifikasi PCR-SSR DNA menggunakan gel agarosa $2 \%$ dengan primer CMCT160a+b M: Marker 50 bp; (1) Tacapa, (2) Tania, (3) Talita, (4) Apollo, (5) Orio, (6) Mai 119, (7) Fantasy, (8) Putri Kencana, (9) Kalila, (10) Ladika, (11) Virgo, (12) Elegant, (13) Sun Lady, (14) PI 371795, (15) Action 434, (16) Honey Globe, (17) Sky Rocket, (18) Sonya, dan (19) Hercules. 

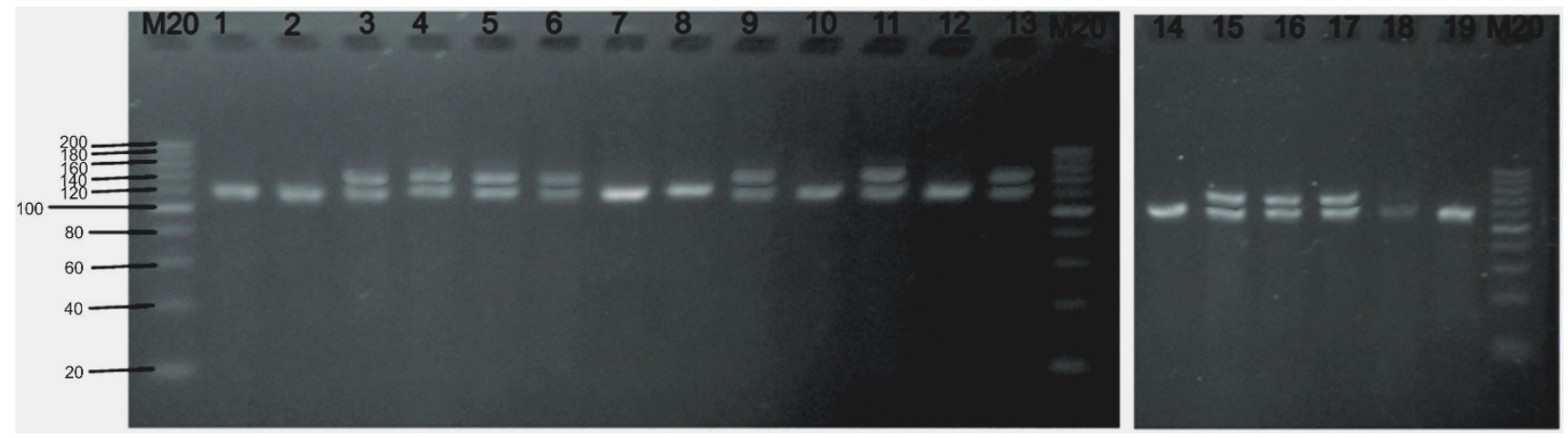

Gambar 4. Hasil amplifikasi PCR-SSR DNA menggunakan gel agarosa 3,8\% dengan primer CMTA170a (1) Tacapa, (2) Tania, (3) Talita, (4) Apollo, (5) Orio, (6) Mai 119, (7) Fantasy, (8) Putri Kencana, (9) Kalila, (10) Ladika, (11) Virgo, (12) Elegant, (13) Sun Lady, (14) PI 371795, (15) Action 434, (16) Honey Globe, (17) Sky Rocket, (18) Sonya, dan (19) Hercules.
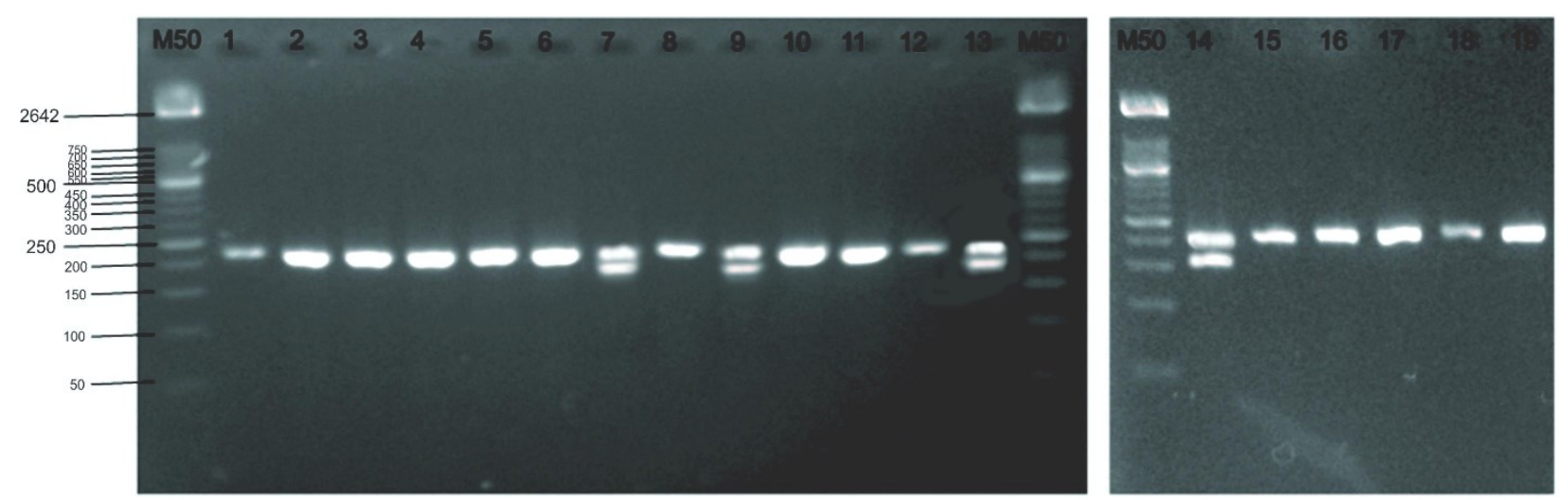

Gambar 5. Hasil amplifikasi PCR-SSR DNA menggunakan gel agarosa 3,8\% dengan primer CMCT160a+b (1) Tacapa, (2) Tania, (3) Talita, (4) Apollo, (5) Orio, (6) Mai 119, (7) Fantasy, (8) Putri Kencana, (9) Kalila, (10) Ladika, (11) Virgo, (12) Elegant, (13) Sun Lady, (14) PI 371795, (15) Action 434, (16) Honey Globe, (17) Sky Rocket, (18) Sonya, dan (19) Hercules.

\section{Simpulan dan Saran}

\section{Simpulan}

Melalui penanda molekular Simple Sequence Repeat (SSR) dapat dideteksi adanya gen ketahanan terhadap gummy stem blight. Pada seluruh kultivar melon yang diuji, baik kultivar melon unggul hasil pengembangan Laboratorium Genetika yaitu 'TACAPA', TANIA', dan 'TALITA' maupun melon komersial diketahui adanya gen ketahanan terhadap gummy stem blight baik bersifat homozigot maupun heterozigot.

\section{Saran}

Perlu dilakukan penelitian lanjutan terhadap gen pembawa sifat ketahanan terhadap gummy stem blight yang lain dengan menggunakan primer yang berbeda sehingga dapat menghasilkan tanaman melon yang tahan terhadap penyakit GSB.

\section{Ucapan Terima Kasih}

Terima kasih saya sampaikan kepada Kementerian Riset dan Teknologi Republik Indonesia yang telah mendukung dan mendanai penelitian ini melalui program Grant Insinas Kemenristek Tahun Anggaran 2014, No: RT2014-123. 


\section{Daftar Pustaka}

Adalberto, C., Filho., C., Santos. G.R. dan Laranjeira F.F. 2010. Temporal and spatial dynamics of watermelon gummy stem blight epidemics. European Journal of Plant Pathology, 128: 473-482.

Anonim. 2015. Basis Data Statistik Pertanian. Departemen Pertanian Republik Indonesia, 2015. http://www.deptan.go.id/tampil.php?page=inf. [2 Januari 2015].

Carmen de vecente, M. dan Fulton, T. 2003. Using Molecular Marker Technology in Studies on Plant Genetic Diversity. International Plant Genetic Resources Institute and Cornell University. Italy and New York.

Choi, I.Y., Choi, J.N., Choi, D.C., Sharma, P.K. dan Lee, W.H. 2010. Identification and Characterization of the Causal Organism of Gummy Stem Blight in the Muskmelon (Cucumis melo L.). Mycobiology, 38 (3): 166-170.

Franzt, J.D. dan Jahn, M.M. 2004. Five independent loci each control monogenic resistance to gummy stem blight in melon (Cucumis melo L.). Theor Appl Genet., 108: 1033-1038.

Furukawa, T., Ono, Y. dan Kishi, K. 2007. Gummy stem blight of balsam pear caused by Didymella bryoniae and its anamorph Phoma cucurbitacearum. Journal Gen Plant Pathology, 73: $125-128$.

Grube, M., Furnkranz, M., Zitzenbacher, S., Huss, H. dan Berg, G. 2011. Emerging multi-pathogen disease caused by Didymella bryoniae and pathogenic bacteria on Styrian oil pumpkin. European Journal of Plant Pathology, 131: 539-548.

Keinath, A.P., Farnham, M.W. dan Zitter, T.A. 1995. Morphological, Pathological, and Genetic
Differentiation of Dydymella bryoniae and Phoma spp. Isolated From Cucurbits. Ecology and Epidemiology, 85 (3): 364-369.

Koolman, J. dan Rohm, K.H. 1994. Color Atlas Biochemistry. Rudigerstrabe 14, D-70469 Stuttgart, Germany.

Lou, L., Wang, H., Qian, C., Liu, J. dan Chen, J. 2013. Genetic mapping of gummy stem blight (Didymella bryoniae) resistance genes in Cucumis sativus-hystrix introgression lines. Euphytica, 192: 359-369.

Sambrook, J. dan Russell, D.W. 2001. Molecular Cloning A Laboratory Manual $3^{\text {rd }}$ Edition. Cold Spring Harbor Laboratory Press. New York.

Utkhede, R.S. dan Koch, C.A. 2002. Evaluation of biological and chemical treatments for control of gummy stem blight on cucumber plants grown hydroponically in greenhouses. BioControl, 49: 109-117.

Wolukau, J.N., Zhou, X.H., Li. Y., Zhang, Y.B. dan Chen, J.F. 2009. Resistance to Gummy Stem Blight in Melon (Cucumis melo L.) Germplasm and Inheritance of Resistance from Plant Introductions 157076, 420145, and 323498. HORTSCIENC, 42 (2): 215-221.

Ying, W.H., Tao, Q.C., Li-na., L., Qun-feng, L.Z., Yongbing, Hong-ping, Y., Ming-Zhu, W., Jin-feng, C. 2012. A SSR Marker Linked to Gsb-4 Loci Resistance to Gummy Stem Blight in Melon. Acta Horticulturae Sinica, 39 (3): 574-580.

Zhang, J., Bruton, B.D. dan Biles, C.L. 2014. Cell walldegrading enzymes of Didymella bryoniae in relation to fungal growth and virulence in cantaloupe fruit. European Journal of Plant Pathology, 139: 749-761. 